\title{
Timing of Eating to Eradicate Diabetes: Simple Solutions to Complex Problems
}

\section{Akbar Nikkhah*}

Department of Animal Sciences, University of Zanjan, Iran

This editorial highlights the importance of future research on ascertaining optimal times of eating certain nutrients for today's man exposed to a variety of environmental stresses. Recent accomplishments in animal and human physiology have contributed to urgency for creating innovative research on timing of nutrient intake [1-4]. These findings suggest that feeding and eating times during the $24 \mathrm{~h}$ period matter in how efficiently nutrients are utilized and partitioned into different tissues notable splanchnic and peripheral tissues. Shifting eating time from morning to evening in once-daily fed dairy and beef cattle has increased nutrient efficiency and milk fat and energy production. Such effects have mainly been resulted from altered circadian and postprandial rhythms of nutrient intake and energyyielding metabolites and hormones [2-4]. On the other hand, evidence exists that human glucose intolerance and insulin resistance develop as day ends and night begins. Thus, despite the discovery that evening feeding may improve production and economics in food-producing animals, due to inter-species differences in evolutionary intermediary metabolism and eating behaviour, it could seriously impair the human physiology and health.

Timing of eating would be among simple feasible solutions for complex challenges such as obesity, diabetes and related cardiovascular diseases frequently encountered by the modern and postmodern human populations worldwide. Manipulating the eating timing would help human to shift back into his evolutionary and natural life-style when optimal timing of eating, working, resting and exercising can significantly contribute to living a healthier and greater quality life.
This philosophy would concur with a leading global memorandum that prevention as a foremost health-promoting strategy is superior to, and eliminates the need for, treatment.

In a nutshell, innovative research on circadian clock genes in all possible tissues, nutribiochemogenomical pathways in drained-viscera, hepatic and peripheral cells and on nutrient intake and metabolism rhythms in response to varying intake timing of different nutrients will be greatly road-mapping. An ultimate goal is to discover clear-cut global guidelines on when to eat which nutrient more or less to help approach optimal cell, tissue, organ and whole body physiology and health in the overly stressed man of the new times.

\section{Acknowledgments}

Thanks to The Ministry of Science, Research and Technology of Iran and University of Zanjan for supporting the author's global programs of optimizing science edification in the new millennium.

\section{References}

1. Dietary Reference Intakes (DRI) (2007) Recommended Intakes for Individuals, Food and Nutrition Board, Institute of Medicine, National Academies. National Academy of Sciences, Washington, D.C. USA.

2. Nikkhah A (2013) Chronophysiology of ruminant feeding behavior and metabolism: an evolutionary review. Biol. Rhythm Res 44: 197-218.

3. Nikkhah A (2012) Time of Feeding an Evolutionary Science, Lap Lambert Publishing, GmbH \& Co. KG, Germany, ISBN 978-3-8473-3260-2.

4. Nikkhah A (2011) Science of eating time: A novel chronophysiological approach to optimize glucose-insulin dynamics and health. J. Diabetes Mellitus 2: 8-11.
*Corresponding author: Akbar Nikkhah, Chief Highly Distinguished Professor, Department of Animal Sciences, Faculty of Agricultural Sciences, University of Zanjan, Zanjan 313-45195 Iran, Tel: +98 241 515280; E-mail: nikkhah@znu.ac.ir

Received July 28, 2014; Accepted July 31, 2014; Published August 08, 2014

Citation: Nikkhah A (2014) Timing of Eating to Eradicate Diabetes: Simple Solutions to Complex Problems. J Diabetes Metab 5: e117 doi:10.4172/21556156.1000e117

Copyright: (c) 2014 Nikkhah A. This is an open-access article distributed under the terms of the Creative Commons Attribution License, which permits unrestricted use, distribution, and reproduction in any medium, provided the original author and source are credited. 